Научная статья

УДК 37.075

DOI: $10.18101 / 2307-3330-2021-4-70-74$

\title{
ФОРМИРОВАНИЕ ФУНКЦИОНАЛЬНОЙ ГРАМОТНОСТИ УЧИТЕЛЕЙ И ОБУЧАЮЩИХСЯ КАК СРЕДСТВО ПОВЫШЕНИЯ КАЧЕСТВА ОБРАЗОВАНИЯ
}

\author{
(C) Обедина Светлана Валентиновна \\ заместитель директора по УВР, учитель русского языка и литературы, \\ Кабанская средняя общеобразовательная школа \\ Россия, 671200, с. Кабанск, ул. 8 Марта \\ dimanikkbnk@gmail.com
}

\begin{abstract}
Аннотация. В последнее время стали актуальными вопросы, связанные с формированием функциональной грамотности в средней школе. В данной статье рассмотрена функциональная грамотность как средство повышения качества образования. Цель - ознакомление с опытом работы МАОУ «Кабанская СОШ» по формированию функциональной грамотности учителей и обучающихся, а именно: как организовать эффективную работу в образовательном центре цифрового и гуманитарного профиля «Точка роста» и на методической неделе в школе. Автор останавливается на данных направлениях, так как считает, что они способствуют формированию функциональной грамотности и повышению качества образования. Это вызывает интерес у учителей и руководителей образовательных учреждений.

Ключевые слова: функциональная грамотность, качество образования, образовательный центр, методическая неделя, компетенция, личностные, предметные и метапредметные результаты.
\end{abstract}

\section{Для цитирования}

Обедина С. В. Формирование функциональной грамотности учителей и обучающихся как средство повышения качества образования // Вестник Бурятского государственного университета. Образование. Личность. Общество. 2021. № 4. С. 70-74.

Сегодня я хочу поделиться опытом, связанным с работой нашей Кабанской школы в направлении формирования функциональной грамотности. По данной проблеме мы работаем 3-й год, и в 2019 г. начали с всеобучей для педагогов, педсоветов и методических недель по данной тематике, чтобы у учителей создалось представление о том, что такое функциональная грамотность и какого человека можно назвать функционально грамотным.

Само понятие «функциональная грамотность» введено в 1957 году ЮНЕСКО, в России оно появилось в 70-х годах 20 века благодаря Алексею Алексеевичу Леонтьеву - советскому и российскому лингвисту, психологу, доктору психологических наук и доктору филологических наук, действительному члену РАО (1992) и АПСН. Ученый дал следующее определение функционально грамотного человека - это «человек, который способен использовать все постоянно приоб- 
C. В. Обедина. Формирование функциональной грамотности учителей и обучающихся как средство повышения качества образования

ретаемые в течение жизни знания, умения и навыки для решения максимально широкого диапазона жизненных задач в различных сферах человеческой деятельности, общения и социальных отношений» ${ }^{1}$.

В средней школе функциональная грамотность формируется как общеучебная компетенция, которая выражается в личностных, метапредметных, предметных, регулятивных, познавательных и коммуникативных результатах. Одной из основных в образовании становится проектная технология (отсюда, например, введение предмета «Индивидуальный проект» на уровне среднего общего образования) и воспитание способности человека решать жизненные задачи (например, введение предмета «Soft skils» - социальные навыки на уровне основного общего образования).

Аспекты или индикаторы функциональной грамотности школьников: общая, информационная, компьютерная, грамотность действий в чрезвычайных ситуациях, коммуникативная, владение иностранными языками, правовая и общественно-политическая грамотность. Индикаторы функциональной грамотности школьников имеют показатели. Например, общая грамотность: написать сочинение, реферат; считать без калькулятора; отвечать на вопросы, не испытывая затруднений в построении фраз, подборе слов; написать заявление, заполнить какиелибо анкеты, бланки. Например сдача ОГЭ и ЕГЭ, итоговое собеседование в 9 классе, итоговое сочинение по литературе в 11 классе, свободное владение навыками грамотной устной и письменной речи и др.

В современной школе ученики овладевают базовой, читательской, научной, культурной грамотностью. Мы помогаем им развивать любознательность, критическое мышление, коммуникативные навыки, изобретательность, навыки взаимодействия. Ребята учатся творчески подходить к решению задач и проблем, поставленных перед ними. В основе организации учебного процесса системно-деятельностный подход, где главное место отводится активной разносторонней, самостоятельной, познавательной деятельности школьника. В нашей школе создаются все условия для повышения качества образования, для создания квалифицированных кадров, их профессионального роста и педагогического мастерства. Наши учителя в течение учебного года проходят различные курсы повышения квалификации, участвуют в семинарах, форумах муниципального, регионального, российского и международного уровней. Все это подтверждено удостоверениями и сертификатами. И сейчас я расскажу о том, как проходят методические недели и организована работа в образовательном Центре цифрового и гуманитарного профилей «Точка роста».

Центр образования цифрового и гуманитарного профилей «Точка роста» начал свою работу в Кабанской школе с сентября 2020, что позволило выйти образованию школы на новый технологический уровень. Для эффективности работы образовательного Центра необходимо было обеспечить подготовку учителей, в том числе прохождение ими курсов и участие во всероссийских форумах таких Центров в России. 10 педагогов в дистанционном формате прошли курсы по теме «Гибкие компетенции проектной деятельности», «Виртуальная и дополнительная

\footnotetext{
${ }^{1}$ Некоторые проблемы обучения русскому языку как иностранному (психо-лингвистические очерки). Москва: Изд-во МГУ, 1970. 88 с.
} 
реальность», «Содержание и методика преподавания ОБЖ (технологии, финансовой грамотности и предпринимательской деятельности)». В начале учебного года были разработаны положение и программы, составлен перечень функций Центра «Точка роста», составлено расписание, издан приказ. Нормативно-правовая база, на основе которой функционирует Центр «Точка роста» на сайте школы https://kabansk.buryatschool.ru/?section_id $=133$

В кабинете №6 цифрового и гуманитарного профилей проводятся уроки и дополнительные занятия с использованием нового оборудования по таким предметным областям, как информатика, технология, физика. Здесь 4 рабочих зоны для 5 учебных модулей. Первая зона «Программирование в среде Scratch» и работа на платформе «Яндекс.Учебник», данные модули ведетут учителя информатики. Модуль «3D-моделирование» преподает педагог дополнительного образования. Зона обучения по 2 модулям «ГЕО информационных технологий» и «VR/AR» (виртуальной и дополнительной реальности), проводит занятия учитель технологии. Учитель физики организует внеурочные занятия по механическому конструированию.

Помещение 7 кабинета рассчитано для проектной деятельности, оно занировано по принципу сотрудничества,так как подход в организации обучения связан с разной занятостью общего пространства. Создание информационномедийных продуктов под руководством учителя русского языка и литературы стало возможным благодаря поступлению новой техники. Преподавание предмета ОБЖ и дополнительных занятий этого направления стало более практико ориентированным с использованием макетов-тренажоров. Данная зона используется и для проведения мини-конференций, различных встреч, собраний, презентаций. Зона отдыха с мягкими пуфами легко трансформируется в минилекторий, здесь учащиеся создают и защищают свои проекты. Шахматная гостиная. Предмет шахматы включен в расписание 5 классов, их проводит педагог дополнительного образования. По словам учителя, его задача не только научить ребят азам игры в шахматы но и поспособствовать общему интеллектуальному развитию подрастающего поколения.

Переход из кабинета в кабинет является зоной рекреации со своим функционалом. Здесь во время перемен, после уроков ученики могут устроить шахматно-шашечные состязания, организовать выставки.

В кабинетах «Точки роста» проходят Сессии мобильного Кванториума из города Улан-Удэ. Ученики 5-8 классов знакомятся с промышленным дизайном, $3 \mathrm{D}$-моделированием, 3D-сканироваем и $3 \mathrm{D}$-печатью. Для учителей и педагогов дополнительного образования мы проводим экскурсии и обучающие семинары, чтобы учителя могли освоить навыки работы с новым оборудованием и применять его на своих уроках занятиях, мероприятиях.

Данные игры проведены для учеников 5-10 классов. Участниками стали по одному представителю из параллели. Ребята получили материалы с заданиями по 4 направлениям: «Исследователь» (химия и физика), «Газетная утка» (русский язык и ИЗО), «Солнечные дети» и «Буллинг» (воспитательный аспект). Участники команды приняли решение разделиться на группы по два человека, выбрали по одному направлению, а после выполнения заданий представили результаты своей работы другим участникам и экспертам. Общекомандной была работа по буллингу, 
C. В. Обедина. Формирование функциональной грамотности учителей и обучающихся как средство повышения качества образования

участники просмотрели ролики по данной проблеме, ознакомились с задачами и, сделав свой выбор, представили его комиссии. Работа команд была оценена высокими баллами, так как учащиеся показали не только знания по предметам, но и умение креативно мыслить, умение работать в парах и команде. В течение всего мероприятия ученики демонстрировали доброжелательные отношения, заинтересованность к происходящему и выразили желание поучаствовать в такой игре еще раз. Специальные семинары проходят для учителей начальной школы, участвующих в сетевой инновационной площадке Федерального научного центра научноисследовательского института системных исследований РАН «Апробация и внедрение основ алгоритмизации и программирования для начальной школы в цифровой образовательной среде Пиктомир» и в марафоне по формированию функциональной грамотности на образовательной площадке «Яндекс. Учебник».

Во время проведения методических недель по формированию функциональной грамотности учителей и обучающихся у нас проходят не только уроки, внеклассные мероприятия, игры, но и мастер-классы, где педагоги делятся своим педагогическим опытом, знакомят коллег с новыми технологиями, методами, формами обучения. Мы имеем опыт проведения игр по функциональной грамотности для смешанных групп учащихся 5-11 классов. Путем случайного выбора формируются группы, ребята получают материалы с заданиями, например, «Исследователь (по химии и физике), «Газетная утка» (по русскому языку, информатике, ИЗО), «Солнечные дети» и «Буллинг» (воспитательного направления). Участники команд самостоятельно принимают решения, как они будут выполнять задания, в группе, в парах или индивидуально. В конце они представляют результаты друг другу и экспертной комиссии. На итоговых педсоветах демонстрируются лучшие практики в присутствии представителей других школ района, учителя получают сертификаты щкольного и муниципального уровней, что необходимо при аттестации.

Собственными силами мы выпускаем сборники исследовательских и проектных работ учащихся нашей школы. В 2021 году в сотрудничестве с Мариной Геннадьевной Цыреновой, директором ИНО БГУ, издали сборник методических материалов «Функциональная грамотность в контексте ФГОС начального общего, основного общего и среднего общего образования (опыт Кабанской школы Кабанского района).

Может возникнуть вопрос, как и чем измерять уровень сформированности функциональной грамотности? Надо сказать, что данная компетенция формируется в течение всей жизни человека. Выпускники школ показывают уровень функциональной грамотности, сдавая экзамены, заполняя различные документы, участвуя в создании проектов, исследовательских работ, умеют находить информацию из различных источников и перерабатывать ее, владеют компьютером и другими техническими средствами, решают бытовые задачи, владеют навыками устной и письменной речи и т. д. Для педагогов на платформе «Яндекс. Учебник» был проведен интенсив «Я учитель», включающий в себя 4 теста: «Цифровые компетенции педагога», «Работа с трудным поведением», «Компетенции успешного современного учителя», «Компетенции учителя по формированию функциональной грамотности учеников», с оценкой по профилям компетенций. Сертификаты с личными результатами получил каждый педагог, а по школе были выведены 
средние баллы. Цифровая компетенция педагогов составила 68,3\%; умение формировать читательскую грамотность $78 \%$, финансовую $86,4 \%$, математическую $72,6 \%$, креативное мышление 74,4\%, естественно-научную 84,7\%, глобальные компетенции 79,9\%.

В наших планах проведение районных семинаров для заместителей директоров по УВР и учителей предметников; участие в фестивалях «Точек роста» в районе, регионе, России; районная игра для учащихся 5-11 классов по функциональной грамотности «Креативное мышление»; сетевое взаимодействие с другими образовательными организациями; фестиваль функциональной грамотности на школьном и районном уровнях; районная квест игра для детей с ОВЗ и инвалидов «Путешествие в мир профессий»; районный конкурс технического конструирования и моделирования и робототехнике «Техностарт»; районный конкурс бизнесидей «Бизнес-старт»; районный турнир по шахматам; районный мастер-класс для учащихся 10-11 классов «Индивидуальный проект. С чего начать?»

Статья поступила в редакциию 02.10.2021; одобрена после рецензирования 13.10.2021; принята к публикации 15.12.2021.

\title{
Литература
}

1. Акатова Т. И. Языковая функциональная грамотность и языковая фигура: психологопедагогический аспект: монография. Москва, 2006. С. 237.

2. Курганов С. Ю. Ребенок и взрослый в учебном диалоге. Москва, 2005. С. 91.

\section{FORMATION OF TEACHERS AND STUDENTS FUNCTIONAL LITERACY AS A MEANS OF THE EDUCATION QUALITY INCREASING}

\author{
Svetlana V. Obedina \\ Deputy Director for education work, Teacher of Russian Language and Literature \\ Kabanskaya secondary school \\ 8 March St., p. Kabansk, 671200, Russia \\ dimanikkbnk@gmail.com
}

Functional literacy in secondary school has recently been mainstreamed. The subject of this article is functional literacy as means of education quality increasing. The purpose of the article is to present the experience of Kabanskaya secondary school developing functional literacy of teachers and students. Our readers will get acquainted with some ways to organize effective work in the educational center of digital and humanities profile "Tochka rosta" and during methodical weeks in school. The author focuses on these areas because she believes that they form functional literacy and improve the quality of education. The article will be useful for teachers and educational managers.

Keywords: functional literacy, quality of education, educational center, methodological week, competence, personal, subject and metasubject results.

The article was submitted 02.10.2021; approved after reviewing 13.10.2021; accepted for publication 15.12.2021. 